\title{
Insecticides and a fungicide affect multiple coral life stages
}

\author{
Kathryn L. Markey ${ }^{1,2}$, Andrew H. Baird ${ }^{3}$, Craig Humphrey ${ }^{2}$, Andrew P. Negri ${ }^{2, *}$ \\ ${ }^{1}$ School of Marine Biology and Aquaculture, and ${ }^{3}$ ARC Centre of Excellence for Reef Studies, James Cook University, \\ Townsville, Queensland 4811, Australia \\ ${ }^{2}$ Australian Institute of Marine Science, PMB 3, Townsville, Queensland 4810, Australia
}

\begin{abstract}
Coral reefs are under threat from land-based agricultural pollutants on a global scale. The vulnerability of early life stages of corals is of particular concern. Here, we compared the sensitivity of gametes, larvae and adult branches of the broadcast-spawning coral Acropora millepora (Ehrenberg) to a number of common pollutants, including 4 classes of insecticides - 2 organophosphates (chlorpyrifos, profenofos), an organochlorine (endosulfan), a carbamate (carbaryl) and a pyrethroid (permethrin) - and a fungicide (2-methoxyethylmercuric chloride, MEMC). Fertilisation of gametes was not affected by any of the insecticides at concentrations up to $30 \mathrm{\mu g} \mathrm{l}^{-1}$. In contrast, settlement and metamorphosis were reduced by between 50 and $100 \%$ following $18 \mathrm{~h}$ exposure to very low concentrations ( 0.3 to $1.0 \mathrm{\mu g} \mathrm{l}^{-1}$ ) of each insecticide class. The insecticides had few visible effects on adult branches following $96 \mathrm{~h}$ exposure to a concentration of $10 \mathrm{\mu g} \mathrm{l}^{-1}$, with the exception of profenofos, which caused polyp retraction, bleaching (i.e. algal symbiont densities were reduced) and a slight reduction in photosynthetic efficiency of the algal symbionts. The fungicide MEMC affected all life-history stages: both fertilisation and metamorphosis were inhibited at $1.0 \mathrm{\mu g} \mathrm{l}^{-1}$, and polyps became withdrawn and photosynthetic efficiency was slightly reduced at $1.0 \mu \mathrm{g} \mathrm{l}^{-1}$. At $10 \mu \mathrm{g}$ $\mathrm{I}^{-1}$ MEMC, branches bleached and some host tissue died. This high susceptibility of coral larvae to pesticides at concentrations around their detection limit highlights the critical need to assess toxicity against all life-history stages of keystone organisms: to focus on mature individuals may underestimate species sensitivity.
\end{abstract}

KEY WORDS: Coral · Reef · Pollution · Insecticide · Fungicide - Fertilisation - Metamorphosis · Pesticide $\cdot$ Settlement

\section{INTRODUCTION}

Reefs on a global scale are under threat from many sources; one of the most insidious is land-based pollutants from current agricultural practices (Rawlins et al. 1998). Large areas of reef, in otherwise relatively unaffected regions, are threatened by the combined assault of increasing turbidity and chemical contaminants (Fabricius 2005). For example, in Australia, $>80 \%$ of the Great Barrier Reef (GBR) catchment area supports some form of agriculture (Gilbert \& Brodie 2001). The scale of this threat has been recognised by the Australian and State Governments which recently initiated a $10 \mathrm{yr}, \$ 40$ million (USD) programme to improve land management practices and to monitor the effectiveness of management on improving water quality on adjacent inshore reefs.

Numerous herbicides, insecticides and fungicides are used in catchments that flow into the GBR lagoon, and up to $74 \mathrm{t}$ of the insecticide chlorpyrifos has been applied annually within catchments of the GBR (Hamilton \& Haydon 1996). Current pesticide concentrations in nearshore tropical environments are largely unknown; however, given the considerable quantities in use, it is not surprising that large accumulations have occasionally been detected. Haynes et al. (2000) recorded concentrations of a number of herbicides and organochlorine insecticides at up to $10 \mu \mathrm{gg}^{-1}$ in sub- 
tidal sediments along the GBR. The insecticide endosulfan has been detected at concentrations as high as $840 \mu \mathrm{g} \mathrm{kg}^{-1}$ in sediment samples from Queensland sugar cane and cotton farms (Müller et al. 2000), and wet season runoff from such highly contaminated farms poses the risk of insecticide transport to nearshore waters of the GBR. In addition to runoff, some reefs, such as those in the Florida Keys, are at risk from exposure to organophosphates, such as dibrom, via accidental mosquitocide overspray (Pierce 1998). Between 500 and $1000 \mathrm{~kg}$ of the fungicide 2methoxyethylmercuric chloride was applied each year for $40 \mathrm{yr}$ in a single catchment that flows into the GBR (Johnson \& Ebert 2000). Mercury concentrations in sediment cores taken from the GBR identified concentrations of up to $100 \mu \mathrm{g} \mathrm{kg}^{-1}$, an order of magnitude higher than background concentrations (Walker \& Brunskill 1997). These concentrations were attributed to the contemporary application of mercury-based fungicides on sugar cane farms (Walker \& Brunskill 1997). The abundance of pollutants in the environment is clearly patchy, and, while more comprehensive sampling is needed to determine the full scale of the problem, these figures demonstrate a clear threat to key organisms such as corals.

Mercury (Rawlins et al. 1998) and banned organochlorine insecticides, such as chlordane, lindane and DDT (Olafson 1978), can accumulate in coral tissue. Preliminary work indicates that Pocillopora damicornis larvae are moderately sensitive to the contemporary insecticides chlorpyrifos and carbaryl, which caused larval mortality only at high concentrations $\left(100 \mathrm{mg} \mathrm{l}^{-1}\right.$ and $1000 \mu \mathrm{g} \mathrm{l}^{-1}$, respectively) (Acevedo 1991). In contrast, adult $P$. damicornis branches were more sensitive to chlorpyrifos in $96 \mathrm{~h}$ exposures, with $50 \%$ of individuals dying at $6 \mu \mathrm{gl}^{-1}\left(\mathrm{LC}_{50}=6 \mu \mathrm{g} \mathrm{l}^{-1}\right)(\mathrm{Te}$ 1998). Some insecticides can also induce changes in gene expression of corals at very low concentrations. For example, the insecticide dibrom caused the up-regulation of 2 genes of unknown function at concentrations of $0.5 \mathrm{\mu g} \mathrm{l}^{-1}$ in adult branches of Acropora cervicornis (Morgan \& Snell 2002). In contrast, neither permethrin nor lindane affected expression at higher concentrations. While the effects of organomercurial insecticides on corals are unknown, inorganic mercury can cause reductions in both polyp and symbiont biomass (Bastidas \& García 2004).

Toxicants can affect corals in a variety of ways. For example, herbicides have been shown to reduce the photosynthesis of coral symbionts (the dinoflagellates Symbiodinium spp.) at low concentrations (Jones \& Kerswell 2003, Negri et al. 2005). Higher concentrations of herbicide can damage the partnership between host and symbiont, resulting in the expulsion (or loss) of symbionts from the coral host (bleaching). However, the specific effects of pesticide groups such as insecticides and fungicides on coral remain virtually unknown. Early events in life, such as fertilisation and larval metamorphosis, may be more sensitive to pollutants than are adults (Mercurio et al. 2004). Most scleractinian corals reproduce by broadcast spawning, with many species releasing gametes for external fertilisation in often highly synchronised seasonal mass spawning events (Harrison \& Wallace 1990). The resulting planula larvae have an obligate planktonic stage of between 2 and $4 \mathrm{~d}$, after which they are competent to settle on the reef (Baird 2004). Larvae of many coral species require a biochemical inducer from crustose coralline algae to trigger metamorphosis (Heyward \& Negri 1999, Baird \& Morse 2004, Harrington et al. 2004). All these developmental stages and events are critical points in the life history of corals, and the failure of any one event will reduce the capacity of populations to be replenished. In the present study, gametes, larvae and adult branches of the broadcast-spawning coral Acropora millepora were exposed to 4 common classes of insecticides and a fungicide (summarised in Table 1) in a series of laboratory experiments to determine the threshold concentrations at which they became toxic to key life-history events and stages.

\section{MATERIALS AND METHODS}

Toxicants. Toxicants were chosen to represent 4 of the main insecticide groups: organophosphates (chlorpyrifos, profenofos), organochlorines (endosulfan), carbamates (carbaryl) and pyrethroids (permethrin) plus a fungicide (2-methoxyethylmercuric chloride, MEMC). Table 1 summarises the usages and modes of action for each of the toxicants. The insecticides and MEMC were sourced from Sigma-Aldrich, and chlorpyrifos and chlorpyrifos oxon were obtained from Dow AgroSciences. Stock solutions of chlorpyrifos, profenofos, endosulfan and permethrin were prepared in GF/C (Whatman) filtered seawater (FSW) using $0.1 \%$ acetone (Merck) to improve dissolution. A stock solution representing the acetone control was prepared in the same way. Treatment concentrations were prepared from dilutions of this stock solution.

Coral collection, broadcast spawning and larval cultivation. Gravid colonies of the broadcast-spawning coral Acropora millepora (Ehrenberg) were collected from 3 to $5 \mathrm{~m}$ depths at High Island, central GBR $\left(17^{\circ} 09.60^{\prime} \mathrm{S}, 146^{\circ} 00.34^{\prime} \mathrm{E}\right)$ and maintained in flowthrough outdoor aquaria $\left(27^{\circ} \mathrm{C}\right)$ at the Australian Institute of Marine Science until spawning on 2 November 2004 , at 21:30 h. The symbiont-free gametes were collected and cultured in indoor flow-through aquaria $\left(27^{\circ} \mathrm{C}\right)$ using methods described in Negri \& Hey- 
Table 1. Modes of action and primary usages for the pesticides examined in this study (van Emden \& Service 2004) (MEMC: 2-methoxyethylmercuric chloride)

\begin{tabular}{|c|c|c|c|}
\hline Pesticide group & Representative & Primary usage & Mode of action \\
\hline $\begin{array}{l}\text { Organochlorine } \\
\text { (OC) }\end{array}$ & Endosulfan & $\begin{array}{l}\text { Primarily: Cotton } \\
\text { Also: Fruit \& vegetables, } \\
\text { grains }\end{array}$ & $\begin{array}{l}\text { Antagonises the action of the neurotransmitter } \\
\text { GABA, which induces the uptake of chloride } \\
\text { ions by neurons resulting in uncontrolled excitation }\end{array}$ \\
\hline $\begin{array}{l}\text { Organophosphate } \\
\text { (OP) }\end{array}$ & $\begin{array}{l}\text { Chlorpyrifos } \\
\text { (Chlorpyrifos } \\
\text { oxon) } \\
\text { Profenofos }\end{array}$ & $\begin{array}{l}\text { Primarily: Sugarcane } \\
\text { Also: Cotton, fruit \& vegetables, } \\
\text { grains, termites, domestic pests, } \\
\text { mosquitos, veterinary } \\
\text { Primarily: Cotton }\end{array}$ & $\begin{array}{l}\text { Inhibits acetylcholinesterase (AChE) in nerve } \\
\text { synapses, leading to build-up of acetylcholine } \\
\text { (ACh) at nerve junctions, producing constant } \\
\text { nervous stimulation. While profenofos is able } \\
\text { to inhibit AChE directly, chlorpyrifos needs to } \\
\text { undergo metabolic conversion to the active } \\
\text { form, chlorpyrifos oxon }\end{array}$ \\
\hline Carbamate & Carbaryl & $\begin{array}{l}\text { Primarily: Sugarcane, cotton } \\
\text { Also: Fruit \& vegetables, } \\
\text { grains, termites, domestic pests, } \\
\text { veterinary }\end{array}$ & $\begin{array}{l}\text { Reversible acetylcholinesterase inhibition, again } \\
\text { leading to build-up of ACh }\end{array}$ \\
\hline Pyrethroids & Permethrin & $\begin{array}{l}\text { Primarily: Cotton } \\
\text { Also: Mosquitos, fruit \& vege- } \\
\text { tables, grains, domestic pests }\end{array}$ & $\begin{array}{l}\text { Inactivation of the nerve junction by prolonged } \\
\text { opening of the sodium channels in synapses }\end{array}$ \\
\hline Fungicide & MEMC & Primarily: Sugarcane seed & $\begin{array}{l}\text { Denaturation of membranous and intra-cellular } \\
\text { proteins and inactivation of enzymes }\end{array}$ \\
\hline
\end{tabular}

ward (2000). In the adult exposure treatments, small branches (4 to $5 \mathrm{~cm}$ ) were cut from mature colonies of A. millepora and attached upright to $2 \mathrm{~cm}^{2}$ glass tiles using Loctite instant adhesive (Henkel). The branch clones were allowed to heal and acclimate in an outdoor flow-through tank for $2 \mathrm{wk}$ prior to treatment.

Fertilisation assays. Gametes from 3 colonies were selected for fertilisation experiments, 1 colony providing the eggs and 2 others the sperm. The egg-sperm bundles from each colony were gently agitated to separate the eggs and sperm into 2 layers. The buoyant eggs were then isolated from the sperm by gentle suction and washed several times in sperm-free, $0.2 \mu \mathrm{m}$ filtered seawater. Sperm concentrations were measured from 2 further colonies using a haemocytometer, and a concentrated sperm mixture was prepared from equal sperm concentrations of each colony. Eggs and sperm were then transferred into $20 \mathrm{ml}$, acetonewashed glass scintillation vials (100 eggs and $10^{6}$ sperm per $10 \mathrm{ml}$ FSW) (Negri \& Heyward 2000). Four replicate vials were used for each toxicant treatment ( 0.3 to $30 \mu \mathrm{g} \mathrm{l}^{-1}$ ), and control treatments consisted of a no toxicant treatment and an acetone treatment (equivalent volume of acetone stock as added in the maximum toxicant treatment). Vials were loosely lidded and maintained under low light at $27^{\circ} \mathrm{C}$. The eggs and embryos were fixed with $5 \%$ Bouins solution after $3 \mathrm{~h}$, when early cell cleavage had reached a maximum endpoint (Heyward 1988). Fertilisation levels were quantified using a dissecting microscope.
Metamorphosis assays. Larvae $6 \mathrm{~d}$ old were preexposed to toxicants or controls for $18 \mathrm{~h}$ in $20 \mathrm{ml}$, acetone-washed scintillation vials. Each vial contained approximately 15 larvae and $10 \mathrm{ml}$ of $0.2 \mu \mathrm{l}$ filtered seawater along with toxicants (30 to $300 \mu \mathrm{g} \mathrm{l}^{-1}$ ) and/or seawater and acetone controls. After $18 \mathrm{~h}$ the larvae were transferred to sterile 6 well polystyrene cell culture plates $(12 \mathrm{ml}, \mathrm{Nunc})$ at $27^{\circ} \mathrm{C}$ and $120 \mu \mathrm{mol}$ quanta $\mathrm{m}^{-2} \mathrm{~s}^{-1}$ under a 12:12 h light:dark cycle. Stock methanolic extract prepared from the crustose coralline alga species Neogoniolithon fosliei and Hydrolithon onkodes (15 $\mu \mathrm{l}$ ) was added to each well to induce metamorphosis, and percent metamorphosis was assessed after 18 h (Heyward \& Negri 1999). Metamorphosis was defined as the initiation of deposition of the basal plate, which is clearly visible through the juvenile coral tissue within $12 \mathrm{~h}$ of settlement in the Acropora (Babcock et al. 2003). This assay procedure was repeated using $7 \mathrm{~d}$ old larvae, with toxicant concentrations ranging from 1.0 to $30 \mu \mathrm{g} \mathrm{l}^{-1}$, and again with $8 \mathrm{~d}$ old larvae, at concentrations ranging from 0.1 to $1.0 \mu \mathrm{g}^{-1}$.

Adult exposures. Adult exposure experiments were carried out in replicate $12 \mathrm{l}$ glass flow-through chambers with dual peristaltic pumps (16 channel Masterflex L/S) delivering both $1 \mu \mathrm{m}$ FSW and toxicant stock to each tank. Water velocity of $5 \mathrm{~cm} \mathrm{~s}^{-1}$ was maintained in the O-shaped tanks using submerged propellers. Metal halide lamps provided illumination of 140 to $160 \mu \mathrm{mol}$ quanta $\mathrm{m}^{-2} \mathrm{~s}^{-1}$ during 12:12 h light:dark cycles over $96 \mathrm{~h}$. Each tank contained 6 branchlets 
(2 branchlets from each colony), and duplicate tanks were used for each treatment. Branches were monitored at $96 \mathrm{~h}$ to check on tentacle condition (feeding or retracted) and ability to respond to disturbance (gentle prodding with stainless steel forceps). Visible bleaching (paling), tissue sloughing and partial or whole branchlet mortality were also recorded at $96 \mathrm{~h}$.

The photosynthetic efficiency of symbiotic dinoflagellates was examined using a pulse-amplitude modulation (PAM) fluorometer (Jones et al. 2003). Maximum effective quantum yield of light-adapted symbionts $\left(\left[F_{\mathrm{m}}{ }^{\prime}-F\right] / F_{\mathrm{m}}{ }^{\prime}=\Delta F / F_{\mathrm{m}}{ }^{\prime}\right)$ was measured using a MINIPAM (Walz). Eight measurements were taken per branch, using a $2 \mathrm{~mm}$ fibre optic sensor held perpendicular to the coral tissue. $\Delta F / F_{\mathrm{m}}{ }^{\prime}$ measurements were taken $6 \mathrm{~h}$ into each light cycle under constant illumination of $140 \mu \mathrm{mol}$ quanta $\mathrm{m}^{-2} \mathrm{~s}^{-1}$. Dinoflagellate densities were measured for each branchlet as per Jones (1997) and expressed on the basis of surface area determined using the wax method of Stimson \& Kinzie (1991).

Cholinesterase assay. Organophosphates such as chlorpyrifos and profenofos inhibit cholinesterase (ChE) activity (see Table 1), so attempts were made to measure ChE activity in corals and apply this to organophosphate-treated branches. Branches from 3 Acropora millepora colonies were used in a preliminary study to test for ChE activity. Coral tissue was obtained from branches using 3 methods (crushing, tissue stripping into phosphate buffer and tissue stripping into FSW) to determine which method would yield higher ChE activity. One set of branches from each colony was ground to a fine powder in liquid nitrogen and extracted in $4 \mathrm{ml}$ of phosphate buffer (pH 7.0) containing $1 \%$ Triton $\mathrm{X}$. The samples were then centrifuged at $4000 \times g$ at $4^{\circ} \mathrm{C}$ for $30 \mathrm{~min}$, and the supernatant was stored at $-80^{\circ} \mathrm{C}$. An airbrush was used to strip the coral tissue from the remaining branches into either $4 \mathrm{ml}$ of ice-cold FSW or $4 \mathrm{ml}$ of phosphate buffer. The samples stripped into FSW were homogenised and then centrifuged at $1600 \times g$ for $5 \mathrm{~min}$ to remove the symbionts. Then, $0.1 \%$ Triton $\mathrm{X}$ solution was added to both FSW and phosphate buffer samples, which were subsequently homogenised and sonicated before being centrifuged at $4000 \times g$ at $4^{\circ} \mathrm{C}$ for $30 \mathrm{~min}$; the supernatant was stored at $-80^{\circ} \mathrm{C}$.

ChE activity was determined spectrophotometrically by the method of Ellman et al. (1961) as modified for microplate reading by Bocquene \& Galgani (1998). To each well of the microplate, $300 \mu \mathrm{l}$ of $0.02 \mathrm{M}$ sodium phosphate buffer ( $\mathrm{pH} 7.0), 20 \mu \mathrm{l}$ of dithiobisnitrobenzoic acid (DTNB $0.01 \mathrm{M}$ ) and $10 \mu \mathrm{l}$ of sample were added successively. After a 5 min incubation, $10 \mu \mathrm{l}$ of either acetylthiocholine (ACTC $0.1 \mathrm{M}$ ), propioylthiocholine (PrSCh $0.1 \mathrm{M}$ ), or butyrylthiocholine (BuSCh
$0.1 \mathrm{M}$ ) was added to start the reaction. Enzyme kinetics were monitored on a microplate reader (Wallac Spectra II) at $405 \mathrm{~nm}$ for $2 \mathrm{~min}$. Each of the 3 tissue preparation techniques was tested at 4 tissue concentrations $(5,10,20$ and $50 \mu \mathrm{l}$ of the volume of sample, the amount of sodium phosphate buffer was adjusted accordingly) and with the 3 substrate types mentioned above.

Data analysis. Percentage data were arcsine transformed to improve normality and homogeneity of variance; the mean percent fertilisation and metamorphosis, dinoflagellate density, or $\Delta F / F_{\mathrm{m}}{ }^{\prime}$ was compared among treatments using a series 1-way ANOVA. The Tukey Honestly significant Difference test was used to determine which means were different. Statistical analyses were performed using Statistica 6.0 (StatSoft). The lowest observed effect concentrations (LOEC) were the lowest contaminant concentrations that elicited significant differences (ANOVA, p < 0.05) from the control treatment; 3- and 4-parameter sigmoidal regressions were fitted to the concentration-percent response data using Sigmaplot V7 (Jandel Scientific). The $\mathrm{EC}_{50} \mathrm{~s}$ (concentrations which caused $50 \%$ inhibition) were calculated from the ensuing equations.

\section{RESULTS}

\section{Fertilisation}

High levels $( \pm \mathrm{SE})$ of fertilisation were achieved in controls with $97 \pm 1 \%$ and $98 \pm 1 \%$ fertilisation after $3 \mathrm{~h}$ in no toxicant and acetone control treatments, respectively. None of the insecticide treatments significantly affected fertilisation at concentrations up to $30 \mathrm{\mu g} \mathrm{l}^{-1}$ (Fig. 1, Table 2). The fungicide MEMC, how-

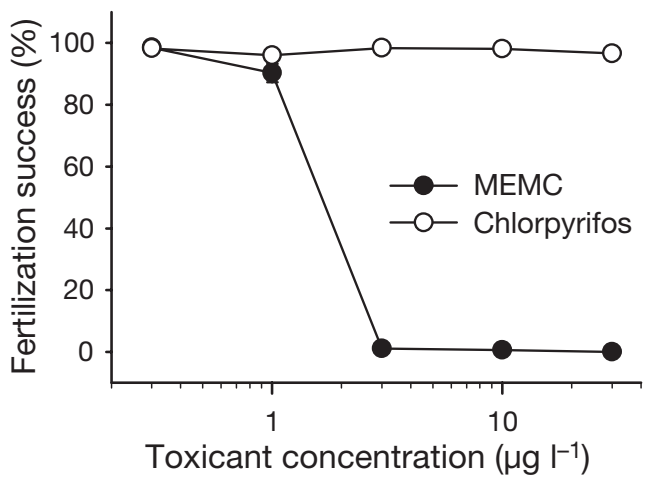

Fig. 1. Acropora millepora. Fertilisation success (\%) for chlorpyrifos and 2-methoxyethylmercuric chloride (MEMC) treatments. Error bars (hidden by symbols) represent $\mathrm{SE}, \mathrm{n}=4$. The other insecticide results were identical to those for chlorpyrifos (see Table 2 for lowest observed effect concentration and estimated $\mathrm{EC}_{50}$ values) 
Table 2. Acropora millepora. Lowest observed effect concentration (LOEC), the concentration that inhibited fertilisation by $50 \%$ $\left(\mathrm{EC}_{50}\right)$ and summary of ANOVA results for fertilisation and the 7 and $8 \mathrm{~d}$ old metamorphosis assays. n.s.: no significant differences $(p>0.05)$. con: control

\begin{tabular}{|c|c|c|c|c|c|c|c|c|}
\hline & Day & $\begin{array}{l}\text { LOEC } \\
\left(\mu \mathrm{g} \mathrm{l}^{-1}\right)\end{array}$ & $\begin{array}{c}\mathrm{EC}_{50} \pm \mathrm{SE} \\
\left(\mu \mathrm{g} \mathrm{l}^{-1}\right)\end{array}$ & SS & df & $F$ & $\mathrm{p}$ & Effect \\
\hline \multicolumn{9}{|l|}{ Fertilisation } \\
\hline Acetone & & & & 0.0015 & 1 & 0.444 & 0.530 & n.s. \\
\hline Endosulfan & & $>30$ & $>30$ & 0.0032 & 5 & 0.466 & 0.796 & n.s. \\
\hline Chlorpyrifos & & $>30$ & $>30$ & 0.0275 & 5 & 1.502 & 0.238 & n.s. \\
\hline Chlorpyrifos oxon & & $>30$ & $>30$ & 0.0107 & 5 & 0.701 & 0.630 & n.s. \\
\hline Profenofos & & $>30$ & $>30$ & 0.0047 & 5 & 0.517 & 0.760 & n.s. \\
\hline Carbaryl & & $>30$ & $>30$ & 0.0139 & 5 & 1.088 & 0.400 & n.s. \\
\hline Permethrin & & $>30$ & $>30$ & 0.0368 & 5 & 1.405 & 0.270 & n.s. \\
\hline MEMC & & 1.0 & $1.68 \pm 0.04$ & 10.7721 & 5 & 416.179 & 0.000 & $\operatorname{con}=0.1=0.3<1=3=10=30$ \\
\hline \multicolumn{9}{|l|}{ Metamorphosis } \\
\hline Acetone & $\begin{array}{l}7 \\
8\end{array}$ & & & $\begin{array}{l}0.0041 \\
0.0009\end{array}$ & $\begin{array}{l}1 \\
1\end{array}$ & $\begin{array}{l}0.212 \\
0.046\end{array}$ & $\begin{array}{l}0.651 \\
0.833\end{array}$ & $\begin{array}{l}\text { n.s. } \\
\text { n.s. }\end{array}$ \\
\hline Endosulfan & $\begin{array}{l}7 \\
8\end{array}$ & 1.0 & $1 \pm 3^{\mathrm{a}}$ & $\begin{array}{c}15.6557 \\
2.5242\end{array}$ & $\begin{array}{l}4 \\
3\end{array}$ & $\begin{array}{l}36.101 \\
37.523\end{array}$ & $\begin{array}{l}0.000 \\
0.000\end{array}$ & $\begin{array}{c}\operatorname{con}<1<3=10=30 \\
\operatorname{con}=0.1=0.3<1\end{array}$ \\
\hline Chlorpyrifos & $\begin{array}{l}7 \\
8\end{array}$ & 1.0 & $1 \pm 2^{\mathrm{a}}$ & $\begin{array}{c}16.3572 \\
0.9299\end{array}$ & $\begin{array}{l}4 \\
3\end{array}$ & $\begin{array}{l}95.803 \\
8.404\end{array}$ & $\begin{array}{l}0.000 \\
0.000\end{array}$ & $\begin{array}{c}\text { con }<1=3=10=30 \\
\text { con }=0.1=0.3<1\end{array}$ \\
\hline Chlorpyrifos oxon & $\begin{array}{l}7 \\
8\end{array}$ & 0.3 & $0.39 \pm 0.01$ & $\begin{array}{l}17.4122 \\
5.9087\end{array}$ & $\begin{array}{l}4 \\
3\end{array}$ & $\begin{array}{l}384.252 \\
64.847\end{array}$ & $\begin{array}{l}0.000 \\
0.000\end{array}$ & $\begin{array}{c}\text { con }<1=3=10=30 \\
\text { con }=0.1<0.3<1\end{array}$ \\
\hline Profenofos & $\begin{array}{l}7 \\
8\end{array}$ & 0.3 & $0.6 \pm 2$ & $\begin{array}{c}15.7026 \\
2.1884\end{array}$ & $\begin{array}{l}4 \\
3\end{array}$ & $\begin{array}{l}91.570 \\
42.753\end{array}$ & $\begin{array}{l}0.000 \\
0.000\end{array}$ & $\begin{array}{c}\text { con }<1=3=10=30 \\
\text { con }=0.1<0.3=1\end{array}$ \\
\hline Carbaryl & $\begin{array}{l}7 \\
8\end{array}$ & 3.0 & $1 \pm 2^{\mathrm{a}}$ & $\begin{array}{c}18.7020 \\
0.0784\end{array}$ & $\begin{array}{l}4 \\
3\end{array}$ & $\begin{array}{c}321.258 \\
1.049\end{array}$ & $\begin{array}{l}0.000 \\
0.387\end{array}$ & $\begin{array}{c}\text { con }=1<3=10=30 \\
\text { n.s. }\end{array}$ \\
\hline Permethrin & $\begin{array}{l}7 \\
8\end{array}$ & 1.0 & $1 \pm 1$ & $\begin{array}{c}15.5260 \\
3.2129\end{array}$ & $\begin{array}{l}4 \\
3\end{array}$ & $\begin{array}{l}44.289 \\
35.944\end{array}$ & $\begin{array}{l}0.000 \\
0.000\end{array}$ & $\begin{array}{c}\text { con }<1=3=10=30 \\
\text { con }=0.1=0.3<1\end{array}$ \\
\hline MEMC & $\begin{array}{l}7 \\
8\end{array}$ & 1.0 & $2.5 \pm 0.3$ & $\begin{array}{c}11.2758 \\
0.1186\end{array}$ & $\begin{array}{l}4 \\
3\end{array}$ & $\begin{array}{c}24.861 \\
1.962\end{array}$ & $\begin{array}{l}0.000 \\
0.144\end{array}$ & $\begin{array}{c}\text { con }<1=3=10<30 \\
\text { n.s. }\end{array}$ \\
\hline
\end{tabular}

ever, reduced fertilisation to $90 \pm 3 \%$ at $1.0 \mu \mathrm{g} \mathrm{l^{-1 }}$ and $1.1 \pm 0.8 \%$ at $3 \mu \mathrm{g} \mathrm{l}^{-1}$. The $\mathrm{EC}_{50}$ for MEMC was $1.68 \pm$ $0.04 \mu \mathrm{g} \mathrm{l}^{-1}$. At $3.0 \mu \mathrm{g} \mathrm{l}^{-1}$ most eggs remained intact, but all eggs had ruptured at $30 \mu \mathrm{g} \mathrm{l}^{-1}$.

\section{Metamorphosis}

Larval metamorphosis in uncontaminated seawater was $77.8 \pm 0.2 \%$ for $6 \mathrm{~d}$ old larvae and this increased to $97.8 \pm 0.9 \%$ and $96.7 \pm 0.9 \%$ for 7 and $8 \mathrm{~d}$ old larvae, respectively. The acetone treatments did not affect metamorphosis significantly (Table 2); 6 d old larvae were exposed to 30, 100 and $300 \mu \mathrm{g} \mathrm{l}^{-1}$ of each toxicant. All toxicants inhibited metamorphosis completely at these concentrations (Fig. 2, Table 2). While most larvae remained swimming at high concentrations of insecticides, $30 \mathrm{gg}^{-1}$ of the fungicide MEMC caused all larvae to rupture and die.

The 7 and 8 d old larvae were exposed to successively lower concentration ranges of each toxicant (1.0, 3.0, 10 and $30 \mu \mathrm{g} \mathrm{l}^{-1}$ for $7 \mathrm{~d}$ and $0.1,0.3$ and $1.0 \mu \mathrm{g} \mathrm{l}^{-1}$ for 8 d larvae). Larval settlement was extremely sensitive to the insecticides, and was reduced by between 60 and $100 \%$ following $18 \mathrm{~h}$ pre-exposures to very low concentrations $\left(0.3\right.$ to $\left.1.0 \mu \mathrm{g} \mathrm{l}^{-1}\right)$. The LOEC was $0.3 \mu \mathrm{g}$ $\mathrm{l}^{-1}$ for chlorpyrifos oxon and profenofos, $1.0 \mu \mathrm{g} \mathrm{l}^{-1}$ for permethrin, endosulfan, chlorpyrifos and MEMC, and $3.0 \mu \mathrm{g} \mathrm{l}^{-1}$ for carbaryl (Fig. 2, Table 2). The insecticides did not affect the swimming behaviour of larvae at any concentration, but larvae exposed to MEMC were often motionless at $3 \mu \mathrm{g} \mathrm{l^{-1 }}$ and above.

\section{Adult branches}

Adult branches of Acropora millepora were exposed to each of the toxicants in 3 successive $96 \mathrm{~h}$ experiments. All branches in no toxicant and acetone controls survived, and no polyp retraction, bleaching, or partial mortality was observed. The tentacles in most of the insecticide treatments were feeding; however, tentacles on branches exposed to $10 \mu \mathrm{g} \mathrm{l}^{-1}$ profenofos and MEMC were permanently retracted after $96 \mathrm{~h}$ 


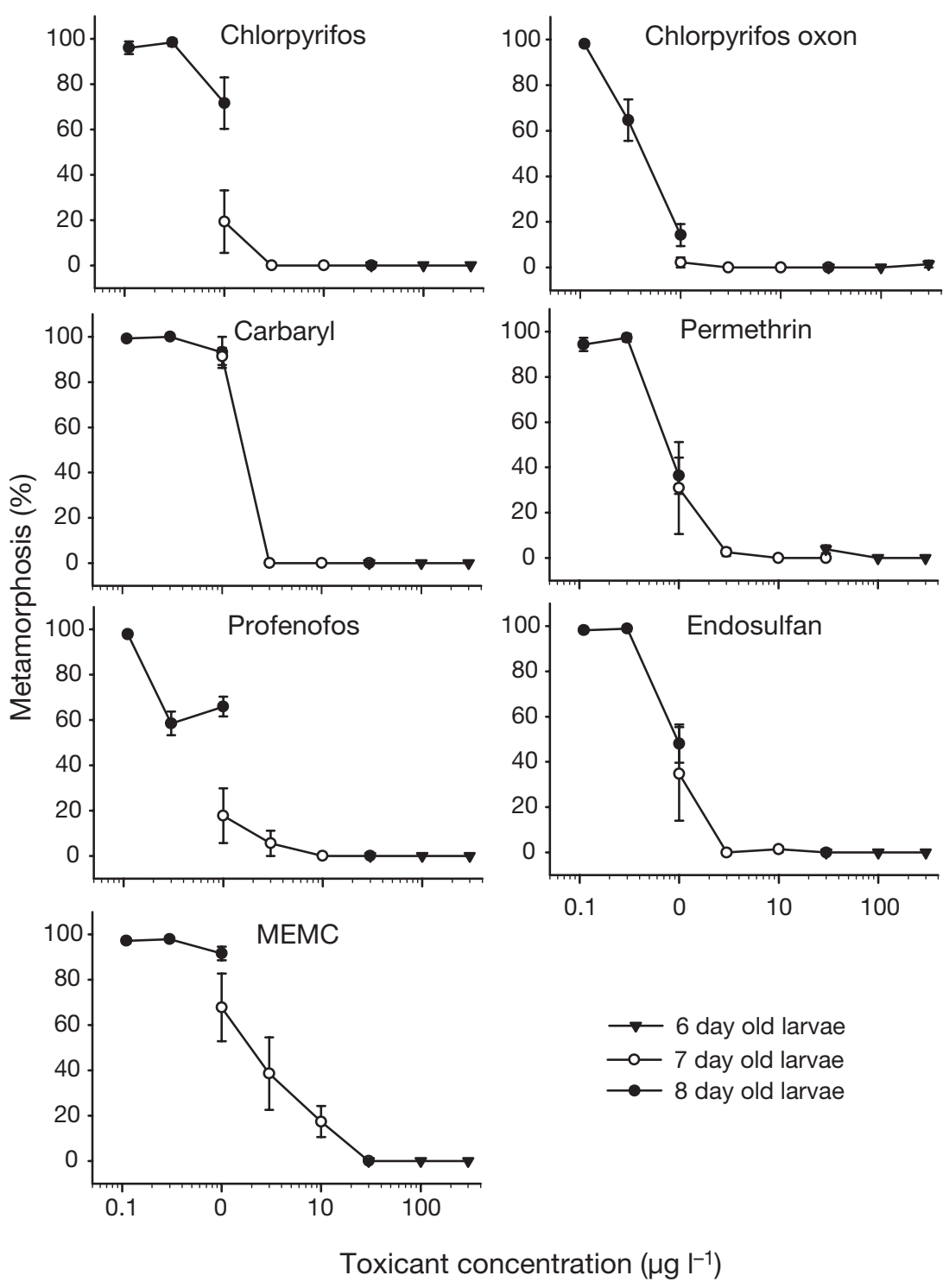

Fig. 2. Acropora millepora. Metamorphosis success (\%) for insecticide and treatments. Bars represent standard errors, $\mathrm{n}=6$ (see Table 2 for lowest observed effect concentration and estimated $\mathrm{EC}_{50}$ values)

skeleton in 7 of the 12 replicate branches (Fig. 3). The maximum effective quantum yields of light-adapted symbionts $\left(\Delta F / F_{\mathrm{m}}{ }^{\prime}\right)$ in Acropora millepora branches were between 0.71 and 0.72 in uncontaminated seawater. Slight but significant reductions in $\Delta F / F_{\mathrm{m}}{ }^{\prime}$ were observed following $96 \mathrm{~h}$ exposures to $10 \mu \mathrm{g} \mathrm{l}$ endosulfan and chlorpyrifos (Tables 3 \& 4). MEMC reduced $\Delta F / F_{\mathrm{m}}{ }^{\prime}$ at both 1 and $10 \mu \mathrm{g} \mathrm{l}^{-1}$ (Tables 3 \& 4). No esterase activity was detectable in coral tissue using 3 common substrates (acetylthiocholine, propioylthiocholine, or butyrylthiocholine_data not shown).

\section{DISCUSSION}

Acropora millepora was highly susceptible to insecticides, with larval settlement and metamorphosis being at least 10 -fold more sensitive to 4 insecticide groups than are mature coral branchlets or oocyte fertilisation. The fungicide MEMC exhibited broader toxicity at very low concentrations across each critical life transition and stage.

The organomercurial fungicide MEMC denatures membrane and intra-cellular proteins and inactivates enzymes causing general metabolic disruption (WHO 1996). Fertilisation is a complex sequence of events, reliant on the action of specific enzymes and proteins that control essential processes such as sperm motility, egg recognition, sperm attachment and penetration of the vitelline layer (Pinto et al. 1990). MEMC would therefore

(Table 3, Fig. 3). Tentacles in the endosulfan, chlorpyrifos, permethrin and carbaryl treatments all retracted normally when contacted gently with stainless steel forceps.

Paling (apparent bleaching) was observed visually on the tips of many branches in $10 \mu \mathrm{g} \mathrm{l}^{-1}$ contaminant treatments, and paling over the entire surface was observed with endosulfan, permethrin and profenofos at this concentration (Table 3). Dinoflagellate densities, however, were only reduced in the presence of $10 \mu \mathrm{g} \mathrm{l}^{-1}$ profenofos and MEMC in comparison with the controls (Tables 3 \& 4). MEMC caused tissue mortality (Tables 3 \& 4), with lesions exposing underlying coral be expected to affect coral fertilisation success, but the LOEC for Acropora millepora of $1.0 \mu \mathrm{g} \mathrm{l}^{-1}$ was surprising as the concentrations required to inhibit external fertilisation of fish eggs are usually orders of magnitude higher (>400 $\mathrm{g} \mathrm{l}^{-1}$ ) (Akiyama 1970). Inorganic mercury (which has a similar mode of action to MEMC; WHO 1996), has been shown to inhibit the fertilisation and development success of ascidian and sea urchin embryos (Franchet et al. 1997), but again at very high concentrations $\left(>400 \mu \mathrm{g} \mathrm{l}^{-1}\right.$ ). The concentration of MEMC that inhibits coral fertilisation is also an order of magnitude lower than that reported for copper (Negri \& Heyward 2001) 
Table 3. Acropora millepora. Effect of each toxicant on polyp retraction, bleaching, tissue mortality ( $>2 \%$ of surface area), dinoflagellate density $( \pm \mathrm{SE})$ and light $\left(\Delta F / F_{\mathrm{m}}{ }^{\prime}\right)$ adapted photosynthetic yields of symbionts. Results for adult branchlet exposures $(\mathrm{n}=12)$. Treatments were performed in 3 consecutive experiments. ${ }^{*}$ Values significantly different from those of the control treatment $\left(\mathrm{p}<0.05\right.$, see Table 4). Low-concentration treatments of dinoflagellate density $\left(1.0 \mu \mathrm{g} \mathrm{l}^{-1}\right)$ not calculated. Polyp retraction: majority of polyps withdrawn without disturbance, remaining in this state for at least $24 \mathrm{~h}$ (effects scored per branchlet). H: heavy bleaching, $>80 \%$ surface; L: light bleaching, $<10 \%$ surface; T: tip bleaching

\begin{tabular}{|c|c|c|c|c|c|c|c|}
\hline Treatment & $\begin{array}{l}\text { Conc. } \\
\left(\mu g l^{-1}\right)\end{array}$ & $\begin{array}{c}\text { Expt } \\
\text { no. }\end{array}$ & $\begin{array}{l}\text { Polyp } \\
\text { retraction }\end{array}$ & $\begin{array}{c}\text { Visual } \\
\text { bleaching }\end{array}$ & $\begin{array}{l}\text { Tissue } \\
\text { mortality }\end{array}$ & $\begin{array}{c}\text { Dinoflagellate } \\
\text { density }\left(\times 10^{4}\right)\left(\text { cells } \mathrm{cm}^{-2}\right)\end{array}$ & $\Delta F / F_{\mathrm{m}}{ }^{\prime}$ \\
\hline Control & $\begin{array}{l}0 \\
0 \\
0\end{array}$ & $\begin{array}{l}1 \\
2 \\
3\end{array}$ & $\begin{array}{l}- \\
- \\
-\end{array}$ & $\begin{array}{l}- \\
- \\
-\end{array}$ & $\begin{array}{l}- \\
- \\
-\end{array}$ & $\begin{array}{l}142 \pm 15 \\
136 \pm 7 \\
163 \pm 12\end{array}$ & $\begin{array}{l}0.72 \pm 0.02 \\
0.71 \pm 0.02 \\
0.71 \pm 0.01\end{array}$ \\
\hline Acetone control & 0 & 1 & - & - & - & $153 \pm 13$ & $0.69 \pm 0.03$ \\
\hline Endosulfan & $\begin{array}{r}1 \\
10\end{array}$ & $\begin{array}{l}1 \\
1\end{array}$ & $\begin{array}{l}- \\
-\end{array}$ & 6/12 $(\mathrm{H})$ & $\begin{array}{l}- \\
-\end{array}$ & $\begin{array}{c}- \\
114 \pm 13\end{array}$ & $\begin{array}{l}0.67 \pm 0.03 \\
0.63 \pm 0.04^{*}\end{array}$ \\
\hline Chlorpyrifos & $\begin{array}{r}1 \\
10\end{array}$ & $\begin{array}{l}1 \\
1\end{array}$ & $\begin{array}{l}- \\
-\end{array}$ & $\begin{array}{c}- \\
5 / 12(\mathrm{~L})\end{array}$ & $\begin{array}{l}- \\
-\end{array}$ & $\begin{array}{c}- \\
127 \pm 9\end{array}$ & $\begin{array}{l}0.69 \pm 0.03 \\
0.65 \pm 0.03^{*}\end{array}$ \\
\hline Profenofos & $\begin{array}{r}1 \\
10\end{array}$ & $\begin{array}{l}3 \\
3\end{array}$ & $\stackrel{-}{12 / 12}$ & $\stackrel{-}{12 / 12}(\mathrm{H})$ & $\begin{array}{l}- \\
-\end{array}$ & $\begin{array}{c}- \\
120 \pm 18^{*}\end{array}$ & $\begin{array}{l}0.69 \pm 0.01 \\
0.71 \pm 0.01\end{array}$ \\
\hline Permethrin & $\begin{array}{r}1 \\
10\end{array}$ & $\begin{array}{l}2 \\
2\end{array}$ & $\begin{array}{l}- \\
-\end{array}$ & $\begin{array}{c}- \\
7 / 12(\mathrm{H})\end{array}$ & - & $\begin{array}{c}- \\
119 \pm 6\end{array}$ & $\begin{array}{l}0.70 \pm 0.02 \\
0.69 \pm 0.02\end{array}$ \\
\hline Carbaryl & $\begin{array}{r}1 \\
10\end{array}$ & $\begin{array}{l}2 \\
2\end{array}$ & $\begin{array}{l}- \\
-\end{array}$ & $\begin{array}{l}- \\
-\end{array}$ & $\begin{array}{l}- \\
-\end{array}$ & $\begin{array}{c}- \\
129 \pm 8\end{array}$ & $\begin{array}{l}0.70 \pm 0.02 \\
0.71 \pm 0.02\end{array}$ \\
\hline MEMC & $\begin{array}{r}1 \\
10\end{array}$ & $\begin{array}{l}3 \\
3\end{array}$ & $\begin{array}{c}1 / 12 \\
12 / 12\end{array}$ & $\begin{array}{l}2 / 12(\mathrm{~T}) \\
5 / 12(\mathrm{~T})\end{array}$ & $\begin{array}{l}1 / 12 \\
7 / 12\end{array}$ & $\begin{array}{c}- \\
118 \pm 9^{*}\end{array}$ & $\begin{array}{l}0.61 \pm 0.01^{*} \\
0.65 \pm 0.01^{*}\end{array}$ \\
\hline
\end{tabular}
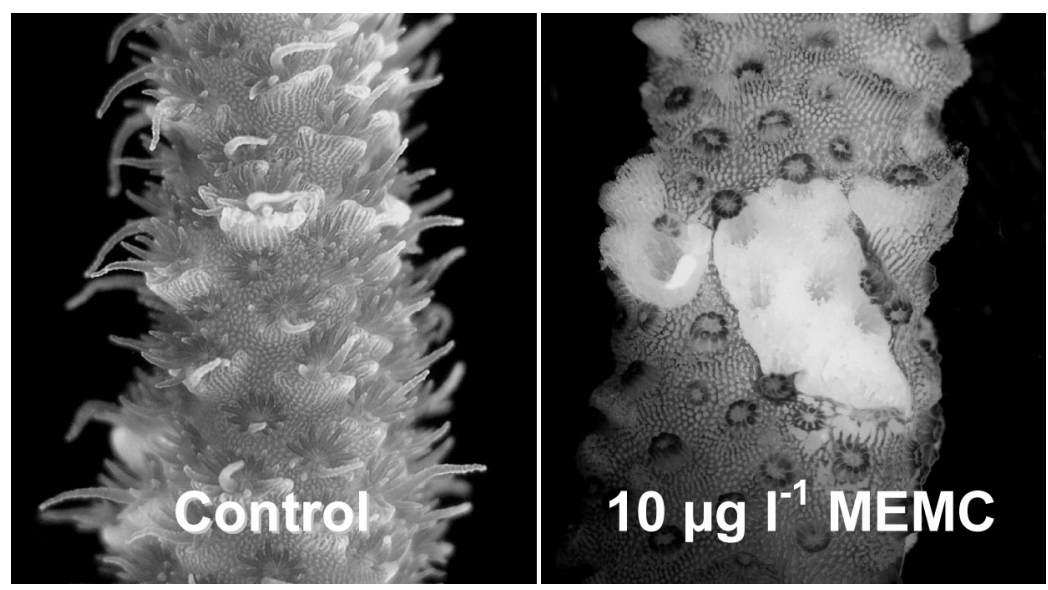

Fig. 3. Acropora millepora. Adult branches. Tentacles are out and feeding on control branchlet, while branchlet exposed to $10 \mathrm{\mu g} \mathrm{l}^{-1}$ MEMC exhibits tissue retraction around the polyps and tissue death exposing underlying skeleton

Insecticides did not inhibit coral fertilisation within the concentration range used in this study. This is perhaps not surprising, because neurons do not develop in Acropora millepora until approximately $50 \mathrm{~h}$ postfertilisation (Ball et al. 2002). Consequently, the inactivity of the neurotoxic insecticides may be due to the lack of nerve-like cells in gametes. However, neurotoxins can affect neuro-transmitters such as AChE in organisms prior to the formation of the nervous system, and there is evidence to suggest they regulate developmental processes such as cell division and differentiation (Buznikov et al. 2001). $\mathrm{AChE}$ is found in ascidian eggs and sperm (Pesando et al. 2003) and in the eggs (Piomboni et al. 2001) of sea urchins. The organophosphate diazinon decreases AChE activity and lectin binding in urchin eggs at $30 \mu \mathrm{g}$ $\mathrm{I}^{-1}$, resulting in a reduction in fertilisation (Pesando et al. 2003). If $\mathrm{AChE}$ is present in $3 \mathrm{~h} \mathrm{~A}$. millepora embryos its function was not affected by chlorpyrifos exposures of up to $30 \mu \mathrm{g} \mathrm{l^{-1 }}$.

The fungicide MEMC was a potent inhibitor of coral settlement and metamorphosis, with an $\mathrm{LC}_{50}$ of $2.5 \pm 0.3 \mu \mathrm{g}$ $\mathrm{I}^{-1}$, second only to the antifoulant TBT (Negri \& Heyward 2001) and more potent than copper (Negri \& Heyward 2001). This toxicity is likely to result from MEMC's ability to denature proteins and inactivate a range of enzymes that are critical to metamorphosis in cnidarians (Leitz 1997).

Coral larval metamorphosis was sensitive to all 4 classes of neurotoxic insecticides. Metamorphosis is an intricate process involving detection of a chemical cue and attachment to a surface by the larvae, and finally cellular differentiation into a sessile juvenile polyp 
Table 4. Acropora millepora. Summary of ANOVA results for $\Delta F / F_{\mathrm{m}}{ }^{\prime}$ and dinoflagellate densities for adult coral branchlet exposures (3 experiments)

\begin{tabular}{|lccccc|}
\hline Parameter & Expt & $\mathrm{SS}$ & $\mathrm{df}$ & \multicolumn{1}{c|}{$F$} & $\mathrm{p}$ \\
\hline$\Delta F / F_{\mathrm{m}}{ }^{\prime}$ & 1 & 0.068 & 5 & 5.481 & 0.000 \\
& 2 & 0.005 & 4 & 1.195 & 0.323 \\
& 3 & 0.080 & 4 & 10.296 & 0.000 \\
Dinoflagellate density & 1 & 1.170 & 3 & 3.745 & 0.018 \\
& 2 & 1.190 & 2 & 1.469 & 0.261 \\
& 3 & 1.719 & 2 & 9.129 & 0.001 \\
\hline
\end{tabular}

(Harrison \& Wallace 1990, Leitz 1997). Coral larvae possess nerve cells after 2 to $3 \mathrm{~d}$, which transform into a diffuse nerve net as the larvae become competent to settle (Ball et al. 2002). RFamide staining of Acropora millepora larvae has revealed the presence of a nerve net spreading along the base of the ectoderm, with distinct sensory neurons projecting from the net to the surface of the ectoderm (Hayward et al. 2001). It is thought that metamorphosis in cnidarians is induced, at least in part, by the release of neuropeptides that spread through the larvae following the stimulation of sensory cells by external cues (Müller \& Leitz 2002). AChE appears to play an integral role in the metamorphosis of some marine larvae, such as ascidians, where AChE activity is sometimes localised on the surface of adhesive papillae prior to settlement (Coniglio et al. 1998). Cholinesterase activity was not confirmed in adult $A$. millepora branches in this study. Low levels of $\mathrm{AChE}$ activity, however, have been identified in soft coral (Horiuchi et al. 2003), using the same type of assay as adopted in the present study. A more sensitive assay may be needed to accurately detect the presence of ChE activity in scleractinian corals.

Small differences in LOECs for metamorphosis were observed among the insecticide treatments (see Table 2). The metabolic conversion of chlorpyrifos to chlorpyrifos oxon is usually required to 'activate' AChE inhibition by this organophosphate (van Emden \& Service 2004). In the present study, chlorpyrifos oxon and profenofos, the 2 organophosphates that are considered toxic without need of oxidative activation, were slightly more potent than the other insecticides. Chlorpyrifos was also toxic, indicating that if the mode of action is related to $\mathrm{AChE}$, then some conversion to chlorpyrifos oxon may have occurred during the $18 \mathrm{~h}$ exposure period. However, studies on the development of sea urchin embryos indicate that chlorpyrifos itself is toxic and may be acting through a different pathway such as the disruption of cholinergic receptors (Buznikov et al. 2001). Although insecticides inhibited metamorphosis at very low concentrations, the larvae were still actively swimming, indicating that the mode(s) of action is much more subtle than MEMC. Larvae of the brooding coral Pocillopora damicornis were also active following exposure to high concentrations of chlorpyrifos and carbaryl (Acevedo 1991). It is likely, therefore, that the insecticides act upon relatively specific neural pathway(s) such as the detection of an external morphogen by sensory cells or one of the internal signalling pathways involved in this critical life-history transition.

In this study, adult coral branches were exposed to only 2 concentrations of each toxicant; however, it was apparent that MEMC was more potent against adults than the insecticides (Table 3). MEMC exposure resulted in polyp retraction and tissue damage at $10 \mu \mathrm{g}$ $\mathrm{l}^{-1}$, indicating a toxic effect on the host animal. The expulsion of dinoflagellates (bleaching) observed at $10 \mu \mathrm{g} \mathrm{l}^{-1}$ plus a reduction in photosynthetic efficiency $\left(\Delta F / F_{\mathrm{m}}{ }^{\prime}\right)$ at $1.0 \mu \mathrm{g} \mathrm{l}^{-1}$ also demonstrates effects on the symbiotic dinoflagellates. These observations are consistent with the broad mode of action of MEMC. The effects on adult corals are similar to those of the antifoulant TBT, which can cause both tissue damage and a slight reduction in photosynthesis at low concentrations (Smith et al. 2003).

The insecticides had little effect on adult branches over the $96 \mathrm{~h}$ exposure periods (Table 3 ). The most noticeable effect was that of profenofos at $10 \mu g \mathrm{l}^{-1}$, where polyp retraction and slight bleaching in all branches were observed. Many of the branches in other treatments appeared to have paled; however, this may have been due to tissue retraction and not a reduction in dinoflagellate density. The organochlorine endosulfan was the only insecticide to have a significant effect on photosynthetic efficiency $\left(\sim 10 \%\right.$ drop at $\left.10 \mu \mathrm{g} \mathrm{l}^{-1}\right)$. The mechanism for this is unclear, but it may be a direct effect on Photosystem II or alternatively an effect on the host, which results in unfavourable conditions for the symbiont. This response contrasts with that of herbicides, which have been shown to consistently inhibit photosynthesis in coral symbionts by $\sim 20 \%$ at $1.0 \mathrm{\mu g} \mathrm{l}^{-1}$ or lower (Jones \& Kerswell 2003, Negri et al. 2005). Adult Acropora millepora appear to be less sensitive to chlorpyrifos than Pocillopora damicornis, which was shown to have an $\mathrm{LC}_{50}$ of $6 \mathrm{\mu g} \mathrm{l}^{-1}$ in $96 \mathrm{~h}$ exposures (Te 1998).

The risk posed by a toxicant to an organism is the product of sensitivity and potential exposure. Information on the environmental concentrations of insecticides and fungicides in nearshore tropical waters where corals may be exposed is scarce; however, the results from this study suggest that all 4 groups of insecticides and the organomercurial fungicide are among the most potent inhibitors of coral fertilisation and/or metamorphosis reported thus far. Therefore, the risks that these pesticides pose to corals, especially reproduction, are potentially significant. 
Commonly used sampling techniques, such as taking integrated water samples from various depths and filtering, may result in an underestimation of the likely exposure faced by multi-life-stage organisms such as corals. For instance, many pesticides, such as chlorpyrifos and endosulfan, are lipophilic and likely to adsorb to particulates, accumulate in sediment and bioaccumulate in planktonic organisms to higher concentrations than the dissolved levels in the water column (Müller et al. 2000). Zooplankton, in particular, can bioaccumulate insecticides to concentrations up to 3000 times higher than ambient water (De Lorenzo et al. 2002). As both autotrophic and heterotrophic organisms, corals may accumulate insecticides directly across membranes, as well as through feeding upon contaminated zooplankton, suspended particulate matter and sediment particles. The sea-surface microlayer (upper $50 \mu \mathrm{m}$ ) is also a concentration point for a range of anthropogenic contaminants, including pesticides, which can be found at concentrations 100s of times higher than in the water column (Hardy et al. 1987). Coral eggs are highly buoyant, and therefore fertilisation may suffer from unrecognised pesticide accumulation on the ocean surface. At settlement, coral larvae are in close contact with marine sediment and biofilms. Pesticides bound to sediments are often present in higher concentrations and persist for longer periods than pesticides in the water column and may be as equally bioavailable as those in solution (Müller et al. 2000). Similarly, biofilms that form on marine surfaces and are critical triggers of coral larval settlement (Webster et al. 2004) can sequester pesticides and prevent settlement in other invertebrates (Labare et al. 1997).

The timing of pollution events can also be a critical factor that may increase the risk to corals. The early life-history stages and transitions of corals, such as spawning, fertilisation, larval dispersal and metamorphosis (recruitment), occur during a finite time period for many species (Harrison \& Wallace 1990). Mass spawning on the GBR generally occurs during November and December each year and may coincide with the first rains of the wet season in tropical North Queensland - the time during which the risk of contamination via terrestrial runoff is nearing its peak for the GBR (Fabricius 2005). Levels of pesticides in suspended sediments and in solution can increase dramatically following the first rainfall of the wet season. For example, chlorpyrifos concentrations in suspended sediment rose from below detection limits to $344 \mu \mathrm{g} \mathrm{l}^{-1}$ in the Lourens River, following the first heavy rains of the South African wet season (Schultz et al. 2001).

Successful reproduction and recruitment is essential for the maintenance of coral reefs, particularly following heavy disturbances, where recovery of coral abun- dance and diversity relies largely on recruitment by larvae or propagules from other reefs (Connell et al. 1997). The early life stages of coral exhibit some of the most sensitive biological responses to pesticide contamination in the marine environment. The extremely high sensitivity of Acropora millepora settlement to a range of insecticides and a fungicide indicates that pesticide contamination of the reef habitat, even by barely detectable concentrations, could have profound consequences for population replenishment. The examination of toxic thresholds provides valuable information that can help management agencies assess risk to key marine organisms. The high sensitivity of corals also raises questions as to whether current sampling and analysis techniques are capable of detecting these low pesticide concentrations and whether water quality guidelines adequately protect all coral life stages.

Acknowledgements. The authors thank J. Mieog for field and laboratory assistance, the AIMS Water Quality Team for providing some of the corals and S. Delean for assistance with statistical interpretation. We thank Dow AgroSciences (Frenchs Forest, Australia) for donating chlorpyrifos and chlorpyrifos oxon.

\section{LITERATURE CITED}

Acevedo R (1991) Preliminary observations on effects of pesticides carbaryl, napthol, and chlorpyrifos on planulae of the hermatypic coral Pocillopora damicornis. Pac Sci45:287-289

Akiyama A (1970) Acute toxicity of two organic mercury compounds to the teleost, Oryzias latipes, in different stages of development. Bull Jpn Soc Sci Fish 36:563-570

Babcock RC, Baird AH, Piromvaragorn S, Thomson DP, Willis BL (2003) Identification of scleractinian coral recruits from Indo-Pacific reefs. Zool Stud 42:211-226

Baird AH (2004) The ecology of coral larvae: settlement patterns, habitat selection and the length of the larval phase. J Proc R Soc NSW 137(1-2):43

Baird AH, Morse ANC (2004) Induction of metamorphosis in larvae of the brooding corals Acropora palifera and Stylophora pistillata. Mar Freshw Res 55:469-472

Ball EE, Hayward DC, Reece-Hoyes JS, Hislop NR, Samuel G, Saint R, Harrison PL, Miller DJ (2002) Coral development: from classical embryology to molecular control. Int J Dev Biol 46:671-678

Bastidas C, García EM (2004) Sublethal effects of mercury and its distribution in the coral Porites astreoides. Mar Ecol Prog Ser 267:133-143

Bocquene G, Galgani F (1998) Biological effects of contaminants: cholinesterase inhibition by organophosphate and carbamate compounds. In: ICES techniques in marine environmental sciences. International Council for the Exploration of the Sea, Copenhagen

Buznikov GA, Lambert HW, Lauder JM (2001) Serotonin and serotonin-like substances as regulators of early embryogenesis and morphogenesis. Cell Tissue Res 305:177-186

Coniglio L, Morale A, Angelini C, Falugi C (1998) Cholinergic activation of settlement in Ciona intestinalis metamorphosing larvae. J Exp Zool 280:314-320 
Connell JH, Hughes TP, Wallace CC (1997) A 30-year study of coral abundance, recruitment, and disturbance at several scales in space and time. Ecol Monogr 67:461-488

De Lorenzo ME, Taylor LA, Lund SA, Pennington PL, Strozier ED, Fulton MH (2002) Toxicity and bioconcentration potential of the agricultural pesticide endosulfan in phytoplankton and zooplankton. Arch Environ Contam Toxicol 42:173-181

Ellman GL, Courtney KO, Andrres V, Featherstone RM (1961) A new and rapid colorimetric determination of acetylcholinesterase activity. Biochem Pharmacol 7:88-95

Fabricius KE (2005) Effects of terrestrial runoff on the ecology of corals and coral reefs: review and synthesis. Mar Pollut Bull 50:125-146

Franchet C, Goudeau M, Goudeau H (1997) Mercuric ions impair the fertilisation potential, the resumption of meiosis, the formation of male pronucleus, and increase in polyspermy, in the egg of the ascidian Phallusia mammillata. J Exp Zool 278:255-272

Gilbert M, Brodie J (2001) Population and major land use in the Great Barrier Reef catchment area: spatial and temporal trends. Great Barrier Reef Marine Park Authority, Townsville

Hamilton D, Haydon G (1996) Pesticides and fertilisers in the Queensland sugar industry-estimates of usage and likely environmental fate. Department of Primary Industries, Brisbane

Hardy JT, Crecelius EA, Antrim LD, Broadhurst VL, Apts CW, Gurtisen JM, Fortman TJ (1987) The sea-surface microlayer of Puget Sound, Part II. Concentrations of contaminants and relation to toxicity. Mar Environ Res 23:251-271

Harrington L, Fabricius K, De'ath G, Negri A (2004) Recognition and selection of settlement substrata determines postsettlement survival in corals. Ecology 85:3428-3437

Harrison PL, Wallace CC (1990) Reproduction, dispersal and recruitment of scleractinian corals. In: Dubinsky Z (ed) Coral reefs. Ecosystems of the world, Vol 25. Elsevier Science Publishing, New York, p 133-207

Haynes D, Muller J, Carter S (2000) Pesticide and herbicide residues in sediments and seagrasses from the Great Barrier Reef World Heritage Area and Queensland coast. Mar Pollut Bull 41:279-287

Hayward DC, Catmull J, Reece-Hoyes JS, Berghammer H, Dodd H, Hann SJ, Miller DJ, Ball EE (2001) Gene structure and larval expression of cnox-2Am from the coral Acropora millepora. Dev Genes Evol 211:10-19

Heyward AJ (1988) Inhibitory effects of copper and zinc sulphates on fertilisation in corals. In: Proc 6th Int Coral Reef Symp. Symposium Executive Committee, Townsville, p 299-303

Heyward AJ, Negri AP (1999) Natural inducers for coral larval metamorphosis. Coral Reefs 18:273-279

Horiuchi Y, Kimura R, Kato N, Fujii T, Seki M, Endo T, Kato T, Kawashima K (2003) Evolutional study on acetylcholine expression. Life Sci 72:1745-1756

Johnson AKL, Ebert SP (2000) Quantifying inputs of pesticides to the Great Barrier Reef Marine Park-a case study in the Herbert River catchment of North-East Queensland. Mar Pollut Bull 41:302-309

Jones RJ (1997) Changes in zooxanthellar densities and chlorophyll concentrations in corals during and after a bleaching event. Mar Ecol Prog Ser 158:51-59

Jones RJ, Kerswell AP (2003) Phytotoxicity of photosystem II (PSII) herbicides to coral. Mar Ecol Prog Ser 261:149-159

Jones RJ, Muller J, Haynes D, Schreiber U (2003) Effects of herbicides diuron and atrazine on corals of the Great Barrier Reef, Australia. Mar Ecol Prog Ser 251:153-167
Labare ML, Coon SL, Matthias C, Weiner RM (1997) Magnification of tributyl tin toxicity to oyster larvae by bioconcentration in biofilms of Shewanella colwelliana. Appl Environ Microbiol 63:3107-4110

Leitz T (1997) Induction of settlement and metamorphosis of cnidarian larvae: signals and signal transduction. Invertebr Reprod Dev 31:109-122

Mercurio P, Negri AP, Burns KA, Heyward AJ (2004) The ecotoxicology of vegetable versus mineral based lubricating oils. 3. Coral fertilization and adult corals. Environ Pollut 129:183-194

Morgan MB, Snell TW (2002) Characterizing stress gene expression in reef-building corals exposed to the mosquitoside dibrom. Mar Pollut Bull 44:1206-1218

Müller JF, Duquesne S, Ng J, Shaw GR, Krrishnamohan K, Manonmanii K, Hodge M, Eaglesham GK (2000) Pesticides in sediments from Queensland irrigation channels and drains. Mar Pollut Bull 41:294-301

Müller WA, Leitz T (2002) Metamorphosis in the Cnidaria. Can J Zool 80:1755-1771

Negri AP, Heyward AJ (2000) Inhibition of fertilization and larval metamorphosis of the coral Acropora millepora (Ehrenberg, 1834) by petroleum products. Mar Pollut Bull 41:420-427

Negri AP, Heyward AJ (2001) Inhibition of coral fertilisation and larval metamorphosis by tributyltin and copper. Mar Environ Res 51:17-27

Negri A, Vollhardt C, Humphrey C, Heyward A, Jones R, Eaglesham G, Fabricius K (2005) Effects of the herbicide diuron on the early life history stages of coral. Mar Pollut Bull 51:370-383

Olafson RW (1978) Effect of agricultural activity on levels of organochlorine pesticides in hard corals, fish and molluscs from the Great Barrier Reef. Mar Environ Res 1: 87-102

Pesando D, Huitorel P, Dolcini V, Angelini C, Guidetti P, Falugi C (2003) Biological targets of neurotoxic pesticides analysed by alteration of developmental events in the Mediterranean sea urchin, Paracentrotus lividus. Mar Environ Res 55:39-57

Pierce RH (1998) Effects of mosquito control measures on non-targeted organisms in the Florida Keys National Marine Sanctuary. Technical Report 609, Mote Marine Laboratory, Sarasota, FL

Pinto MR, Hoshi M, Marino R, Amoroso A, Santis D (1990) Chymotrypsin-like enzymes are involved in sperm penetration through the vitelline coat of Ciona intestinalis egg. Mol Reprod Dev 26:319-323

Piomboni P, Baccetti B, Moretti E, Gambera L, Angeline C, Falugi C (2001) Localization of molecules related to cholinergic signalling in eggs and zygotes of the sea urchin, Paracentrotus lividus. J Submicrosc Cytol Pathol 33:187-193

Rawlins BG, Ferguson AJ, Chilton PJ, Arthurton RS, Rees JG, Baldock JW (1998) Review of agricultural pollution in the Caribbean with particular emphasis on small island developing states. Mar Pollut Bull 36:658-668

Schultz R, Peall SKC, Dabrowski JM, Reinecke AJ (2001) Current-use insecticides, phosphates and suspended solids in the Lourens River, Western Cape, during the first rainfall event of the wet season. Water SA 27:65-71

Smith LD, Negri AP, Phillip E, Webster NS, Heyward AJ (2003) The effects of antifoulant paint contaminated sediments on coral recruits and branchlets. Mar Biol 143: 651-657

Stimson J, Kinzie RA (1991) The temporal pattern and rate of release of zooxanthellae from the reef coral Pocillopora 
damicornis (Linnaeus) under nitrogen-enrichment and control conditions. J Exp Mar Biol Ecol 153:63-67

Te FT (1998) Preliminary investigations into the effects of Dursban registered insecticide on Pocillopora damicornis (Scleractinia: Cnidaria). J Mar Environ Eng 4:189-199

van Emden HF, Service MW (2004) Pest and vector control, Vol 1. Cambridge University Press, Cambridge

Walker GS, Brunskill GJ (1997) Detection of anthropogenic and natural mercury in sediments from the Great Barrier Reef lagoon. In: The Great Barrier Reef. Science, use

Editorial responsibility: Howard Browman (Associate Editorin-Chief), Storebø, Norway and management, Vol 2. Great Barrier Reef Marine Park Authority, Townsville, p 30-36

Webster NS, Smith LD, Heyward AJ, Watts JE, Webb RI, Blackall LL, Negri AP (2004) Metamorphosis of a scleractinian coral in response to microbial biofilms. Appl Environ Microbiol 70:1213-1221

WHO (World Health Organization) (1996) WHO/FAO data sheets on pesticides, No. 66. 2-methoxyethylmercury choride. Available at: www.inchem.org/documents/pds/ pds/pest66_e.htm\#2.1.2

Submitted: March 27, 2006; Accepted: May 31, 2006

Proofs received from author(s): January 9, 2007 